\title{
Perbedaan Kematangan Sosial Siswa yang Berasal dari Sekolah Homogen dan Sekolah Heterogen
}

\author{
Peni Ramanda, Imalatul Khairat \\ Prodi Bimbingan dan Konseling, Fakultas Keguruan dan Ilmu Pendidikan, Universitas Mathla’ul Anwar \\ Banten, Jl. Raya Labuan-Pandeglang No.23, Pandeglang, Banten, Indonesia 42273 \\ E-mail: peniramanda@gmail.com
}

Artikel diterima: 5 Oktober 2017; direvisi 9 Desember 2017; disetujui 13 Desember 2017

\begin{abstract}
The purposes of this study is to describes: (1) the social maturity of students from homogeneous school and heterogeneous schools; (2) to examine whether there is a difference of social maturity levels of students from the homogeneous schools and heterogeneous schools. The samples of this quantitative research are 206 students from Madrasah Aliyah Swasta Ar-Risalah and Madrasah Aliyah Swasta Tarbiyah Islamiyah Batang Kabung. Sample were chosen using proportional random sampling techniques. The instrument used in this research is the scale of the social maturity of students. The data were analyzed with descriptive statistics and t-test. The research findings shows that: (1) the social maturity of students from homogeneous school heterogeneous schools were on a high category; (2) there is a difference of social maturity levels of students from a homogeneous schools and heterogeneous schools, where the level of social maturity of students from heterogeneous schools is higher.
\end{abstract}

Keywords: social maturity; homogeneous school; heterogeneous school

\begin{abstract}
Abstrak: Tujuan penelitian ini adalah untuk mendeskripsikan: (1) kematangan sosial siswa dari sekolah homogen dan sekolah heterogen; (2) untuk menguji apakah ada perbedaan tingkat kematangan sosial siswa dari sekolah homogen dan heterogen. Sampel penelitian kuantitatif ini adalah 206 siswa dari Madrasah Aliyah Swasta (MAS) Ar-Risalah dan MAS Tarbiyah Islamiyah (TI) Batang Kabung. Pemilihan sampel menggunakan teknik proportional random sampling. Instrumen yang digunakan dalam penelitian ini adalah skala kematangan sosial siswa. Data dianalisis dengan statistik deskriptif dan uji-t. Temuan penelitian adalah: (1) kematangan sosial siswa dari sekolah heterogen sekolah homogen berada pada kategori tinggi; (2) terdapat perbedaan tingkat kematangan sosial siswa yang berasal dari sekolah yang homogen dan heterogen, dimana tingkat sosial kematangan siswa yang berasal dari sekolah heterogen lebih tinggi.
\end{abstract}

Kata kunci: kematangan sosial; sekolah homogen; sekolah heterogen

Siswa MAS adalah individu yang berada pada fase remaja. Remaja merupakan salah satu tahap perkembangan yang harus dilalui seorang individu. Ada beberapa tugas perkembangan yang harus dipenuhi remaja, yaitu: (1) mampu menerima keadaan fisik secara positif dan menjalankan peran yang sesuai dengan jenis kelamin; (2) mampu membina hubungan sosial dengan teman sejenis maupun teman yang berbeda jenis kelamin; (3) mampu membangun kemandirian emosional terhadap orang tua dan orang dewasa lainnya; (4) mampu mencapai jaminan kemandirian ekonomi, (5) mampu memilih dan mempersiapkan suatu pekerjaan; (6) mampu mengembangkan keterampilan intelektual dan konsep yang diperlukan untuk kompetensi kewarganegaraan; (7) mampu mencapai perilaku yang bertanggung jawab secara sosial; (8) mampu mempersiapkan pernikahan dan kehidupan keluarga, dan (9) mampu membangun nilai-nilai yang sesuai dengan aturan-aturan yang berlaku (Havighurst dalam Ausubel, 2002) 
Tugas-tugas perkembangan tersebut perlu dicapai oleh remaja agar menjadi individu yang sukses secara psikologis dan siap menyambut tahap perkembangan dewasa. Ketercapaian tugas perkembangan merupakan wujud kematangan yang diperoleh remaja. Ada beberapa kematangan yang perlu dicapai individu di usia remaja. Kematangan tersebut diantaranya: kematangan fisik, pskilogis, dan sosial (Singh, Pant, \& Valentina, 2013). Kematangan sosial sebagai salah satu kematangan yang harus dicapai individu di usai remaja perlu mendapat perhatian agar individu mampu mencapainya dengan sukses di usia remaja. Kematangan sosial merupakan kemampuan individu untuk menilai diri dan beraktivitas sosial sesuai dengan aturan nilai dan norma yang berlaku di masyarakat (Singh et al., 2013), oleh karena itu kematangan sosial sebagai salah satu bentuk kematangan yang harus dicapai individu di usia remaja perlu mendapat perhatian agar tercapai secara optimal.

Aspek kematangan sosial yang dilihat dalam penelitian ini merujuk ke tugas perkembangan sosial yang disampaikan Havighurst (dalam Ausubel, 2002), yaitu: membina hubungan sosial dengan teman sejenis maupun lawan jenis, menjalankan peran sosial yang sesuai dengan jenis kelamin, dan mencapai perilaku sosial yang bertanggung jawab.

Banyak hal yang memengaruhi kematangan sosial, salah satunya adalah lingkungan sekolah. Kematangan akan dicapai oleh individu pada usia remaja kecuali jika lingkungan menghambatnya (Santrock, 2003). Lingkungan sekolah sebagai salah satu faktor yang memengaruhi kematangan sosial, mestinya mampu memfasilitasi individu dalam mencapai kematangan sosial sehingga individu mampu mencapai tahap perkembangan dewasa dengan sukses. Di lapangan, sekolah dapat dibedakan berdasarkan jenis kelamin siswanya. Sekolah tersebut adalah sekolah homogen dan sekolah heterogen. Sekolah homogen merupakan sekolah yang memisahkan antara siswa laki-laki dan perempuan dalam proses belajar dan mengajar ataupun kegiatan lainnya (Indriana \& Windarti, 2008), sedangkan sekolah heterogen adalah sekolah yang tidak memisahkan siswanya berdasarkan jenis kelamin dalam proses belajar dan mengajar ataupun kegiatan lainnya (Mael, 1998).

Pengelompokan siswa berdasarkan jenis kelamin seperti pada sekolah homogen dapat menimbulkan beberapa permasalahan. Masalah tersebut antara lain: (1) rendahnya ketercapaian tugas perkembangan siswa (Putra, 2017); (2) siswa sulit menjalin hubungan sosial karena tidak ada kontak sosial secara langsung antar jenis kelamin (Wahyuni, Dewi, \& Hasratuddin, 2014); (3) siswa cenderung melakukan aktivitas yang berbeda dengan peran sosialnya (Saraswati, 2013); (4) memunculkan isu rasisme (Hughes, 2006); (5) memungkinkan terjadinya perubahan orientasi seksual (Putra, 2017).

Menempatkan siswa tanpa membedakan jenis kelamin seperti pada sekolah heterogen juga dapat menimbulkan beberapa masalah. Masalah tersebut antara lain: (1) hasil belajar lebih rendah dibandingkan siswa di sekolah homogen (Hughes, 2006); (2) siswa di kelas kurang kompetitif (Ormrod, 2016); (3) siswa cenderung kurang bertanggung jawab secara sosial (Ormrod, 2016).

Permasalahan yang dialami siswa di sekolah (termasuk masalah siswa dalam berhubungan sosial) merupakan salah satu tanggung jawab Guru Bimbingan dan Konseling (BK) atau Konselor Sekolah untuk membantu dalam mencarikan jalan keluar. Guru BK atau Konselor Sekolah yang harus mempertimbangkan setiap tindakannya dengan baik (Radjah, 2016) diharapkan mampu memberikan pelayanan BK yang tepat dalam rangka membantu siswa dalam meningkatkan kematangan sosialnya. Di lapangan, sering kali pelayanan BK yang diberikan masih belum optimal dalam membantu siswa meningkatkan kematangan sosialnya.

Berdasarkan kajian keilmuan, diduga terdapat perbedaan kematangan sosial siswa yang berasal dari sekolah homogen dan heterogen, dimana siswa yang berasal dari sekolah heterogen memiliki kematangan sosial yang lebih tinggi dibandingkan siswa yang berasal dari sekolah homogen. Penulisan artikel ini dilakukan untuk mengkaji: tingkat kematangan sosial siswa yang berasal dari sekolah homogen; tingkat kematangan sosial siswa yang berasal dari sekolah heterogen; dan perbedaan kematangan sosial siswa yang berasal dari sekolah homogen dan heterogen. Aspek kematangan sosial yang dilihat dalam penelitian ini merujuk kepada tugas perkembangan sosial yang disampaikan Havighurst (dalam Ausubel, 2002). 


\section{METODE}

Penelitian ini menggunakan pendekatan kuantitatif deskriptif dengan metode penelitian komparatif untuk melihat perbedaan kematangan sosial siswa yang berasal dari sekolah homogen dan heterogen. Populasi penelitian merupakan semua siswa di sekolah MAS Ar-Risalah sebagai sekolah homogen dan MAS TI Batang Kabung sebagai sekolah heterogen. Sampel penelitian berjumlah 206 siswa, yang terdiri dari 146 siswa sekolah homogen dan 60 siswa sekolah heterogen. Teknik pengambilan sampel menggunakan Proportional Random Sampling. Instrumen yang digunakan adalah skala pengukuran kematangan sosial yang memiliki lima alternatif jawaban, yaitu: Sangat Sesuai (SS); Sesuai (S); Cukup Sesuai (CS); Tidak Sesuai (TS); dan Sangat Tidak Sesuai (STS). Untuk mengetahui perbedaan kematangan sosial siswa sekolah homogen dan siswa sekolah heterogen, data dianalisis dengan $t$-test. Analisis data dibantu dengan menggunakan program SPSS versi 20.0 .

Uji persyaratan analisis yang dilakukan pada data penelitian ini adalah uji normalitas dan uji homogenitas. Pengujian normalitas data dilakukan dengan metode Kolmogorov-Smirnov dengan koreksi Lilliefors. Taraf signifikansi yang ditetapkan adalah 0,05 yang berarti bahwa data berdistribusi normal jika $P$-value lebih besar dari taraf signifikan yang ditetapkan, dan sebaliknya. Hasil uji normalitas data, $P$-value data kematangan sosial siswa yang berasal dari sekolah homogen dan heterogen adalah 0,200. Dengan demikian dapat disimpulkan bahwa data kematangan sosial siswa yang berasal dari sekolah homogen dan heterogen berdistribusi normal.

Uji homogenitas yang digunakan dalam penelitian ini adalah uji Levene. Dengan menetapkan taraf signifikan sebesar 0,05. Berdasarkan hasil uji homogenitas, diperoleh $P$-value sebesar 0,115. Oleh karena $P$-value lebih besar dari taraf signifikan yang berarti bahwa tidak signifikan memiliki makna bahwa varians dari kedua kelompok yang dibandingkan adalah homogen.

\section{HASIL}

Data berupa rekapitulasi rata-rata skor dan kategori hasil penelitian kematangan sosial yang diperoleh dari 206 sampel yang berasal dari sekolah homogen dan heterogen disajikan pada Tabel 1. Berdasarkan hasil pengujian yang telah dilakukan, diketahui ada perbedaan kematangan sosial siswa yang berasal dari sekolah homogen dan heterogen, dimana kematangan sosial siswa yang berasal dari sekolah homogen lebih rendah dibandingkan kematangan sosial siswa yang berasal dari sekolah heterogen. Hal tersebut disajikan pada tabel 2.

Pengujian perbedaan berpatokan pada kolom $t$-test for Equality of Means. Hal ini dilakukan karena data bersifat homogen. Berdasarkan kolom $t$-test for Equality of Means, nilai $t_{\text {hitung }}$ lebih besar dari pada $t_{\text {tabel }}(2,175>1,970)$. Selanjutnya, nilai $P$-value lebih kecil dibandingkan dengan taraf signifikansi $(0,31<0,05)$. Apabila nilai $t_{\text {hitung }}$ lebih besar dari $\mathrm{t}_{\text {tabel }}$ dan nilai $P$-value lebih kecil dari taraf signifikan maka dinyatakan memiliki keberartian, dan sebaliknya. Berdasarkan Tabel 2, nilai

$t_{\text {hitung }}$ lebih besar daripada $t_{\text {tabel }}$ dan koefisien $P$-value lebih kecil dari taraf signifikan maka dinyatakan bahwa terdapat perbedaan yang signifikan antara kematangan sosial siswa yang berasal dari sekolah homogen dan heterogen.

Selanjutnya, untuk menentukan tingkat kematangan sosial siswa dari sekolah mana yang lebih tinggi dapat dilakukan dengan melihat besarnya rata-rata skor kematangan sosial siswa masingmasing sekolah. Berdasarkan Tabel 1, diketahui bahwa rata-rata skor kematangan sosial siswa yang berasal dari sekolah homogen lebih rendah daripada rata-rata skor kematangan sosial siswa yang berasal dari sekolah heterogen. Maka, secara keseluruhan dapat diketahui bahwa terdapat perbedaan yang signifikan antara kematangan sosial siswa yang berasal dari sekolah homogen dan heterogen, dimana kematangan sosial siswa yang berasal dari sekolah homogen lebih rendah dibandingkan kematangan sosial siswa yang berasal dari sekolah heterogen. 
Tabel 1 Rekapitulasi Rata-rata Skor dan Kategori Kematangan Sosial Siswa yang Berasal dari Sekolah Homogen dan Heterogen

\begin{tabular}{lcccc}
\hline \multirow{2}{*}{ Kematangan Sosial } & \multicolumn{2}{c}{ Sekolah Homogen (n-146) } & \multicolumn{2}{c}{ Sekolah Heterogen (n-60) } \\
\cline { 2 - 5 } & $\begin{array}{c}\text { Rata-rata } \\
\text { Skor }\end{array}$ & Kategori & $\begin{array}{c}\text { Rata-rata } \\
\text { Skor }\end{array}$ & Kategori \\
\hline $\begin{array}{l}\text { Aspek membina hubungan dengan } \\
\text { teman sejenis }\end{array}$ & 39,41 & Sedang & 44,20 & Tinggi \\
\hline $\begin{array}{l}\text { Aspek mampu menjalankan peran sosial } \\
\text { yang sesuai dengan jenis kelamin }\end{array}$ & 53,12 & Tinggi & 54,33 & Tinggi \\
\hline $\begin{array}{l}\text { Aspek mampu mencapai perilaku sosial } \\
\text { yang bertanggung jawab }\end{array}$ & 67,57 & Tinggi & 66,42 & Tinggi \\
\hline Kematangan sosial secara umum & 160,10 & Tinggi & 164,95 & Tinggi \\
\hline
\end{tabular}

Tabel 2 Hasil Uji Perbedaan (t-test) Kematangan Sosial Siswa yang Berasal dari Sekolah Homogen dan Heterogen

\begin{tabular}{llcccc}
\hline & & \multicolumn{3}{c}{ t-test for equality of means } \\
\cline { 2 - 5 } & $\boldsymbol{t}$ & $\boldsymbol{D f}$ & Sig (2 tailed) & Mean difference \\
\hline $\begin{array}{l}\text { Kematangan } \\
\text { sosial }\end{array}$ & $\begin{array}{l}\text { Equal variances } \\
\text { assumed }\end{array}$ & 2,175 & 204 & 0,031 & 4,854 \\
\cline { 2 - 5 } & $\begin{array}{l}\text { Equal variances } \\
\text { not assumed }\end{array}$ & 2,033 & 95,86 & 0,45 & 4,854 \\
\hline
\end{tabular}

\section{PEMBAHASAN}

\section{Kematangan Sosial Siswa Sekolah Homogen}

Berdasarkan Tabel 1, terlihat bahwa kematangan sosial siswa yang berasal dari sekolah homogen berada pada kategori tinggi dengan rata-rara skor 160,1. Jika dilihat lebih detail ke masing-masing aspek kematangan sosial, terjadi perbedaan rata-rata skor kematangan sosial siswa yang berasal dari sekolah homogen, ada yang sedang dan tinggi.

Aspek pertama yakni membina hubungan sosial dengan teman sejenis maupun lawan jenis berada pada kategori sedang dengan rata-rata skor 39,41. Kategori pada aspek pertama ini merupakan kategori kematangan sosial terendah siswa sekolah homogen. Aspek kedua dan aspek ketiga kematangan sosial siswa yang berasal dari sekolah homogen berada pada kategori tinggi. Rata-rata skor kematangan sosial siswa yang berasal dari sekolah homogen untuk aspek menjalankan peran sosial sesuai dengan jenis kelamin adalah 53,12. Sedangkan rata-rata skor kematangan sosial siswa yang berasal dari sekolah homogen untuk aspek mencapai perilaku sosial yang bertanggung jawab adalah 67,57 .

Hasil analisis deskriptif menunjukkan bahwa rata-rata kematangan sosial siswa yang berasal dari sekolah homogen berada pada kategori tinggi. Hal tersebut menunjukkan bahwa kematangan sosial siswa yang dipisahkan secara jenis kelamin tetap bisa tinggi, karena pada temuan penelitian terlihat bahwa tidak ada siswa dari sekolah homogen memiliki kematangan sosial yang rendah dan sangat rendah.

Disamping faktor internal seperti coping skill (Lestari, Hidayah, Suci, Riza, \& Martuti, 2005; Nicholls, Perry, Jones, Morley, \& Carson, 2013; Sadeghi \& Niknam, 2015), lingkungan juga memberi pengaruh yang cukup signifikan terhadap kematangan sosial. Lingkungan, termasuk lingkungan sekolah merupakan salah satu faktor penting yang memengaruhi kematangan sosial individu. Tingkat kematangan sosial yang tinggi pada sekolah homogen mengisyaratkan bahwa pemisahan siswa berdasarkan jenis kelamin ternyata tidak membuat tingkat kematangan sosial menjadi rendah. Namun, untuk lebih mendalami temuan penelitian, perlu dilihat ketiga aspek dari kematangan sosial tersebut. 


\section{Membina Hubungan Sosial dengan Teman Sejenis dan Lawan Jenis}

Rata-rata kemampuan siswa membina hubungan sosial dengan teman sejenis maupun lawan jenis berada pada kategori sedang dengan skor 39,41. Kategori ini merupakan kategori yang paling rendah siswa dari sekolah homogen untuk semua aspek kematangan sosialnya. Kategori pada aspek ini juga lebih rendah dibandingkan dengan siswa yang berasal dari sekolah heterogen. Hal ini menunjukkan bahwa siswa yang dipisahkan secara jenis kelamin akan lebih kesulitan dalam membina hubungan sosial dengan teman sejenis maupun lawan jenis dibandingkan dengan siswa yang tidak dipisah (Putra, 2017).

\section{Menjalankan Peran Sosial Sesuai dengan Jenis Kelamin}

Salah satu aspek kematangan sosial siswa adalah kemampuan dalam menjalankan peran sosial yang sesuai dengan jenis kelaminnya. Pada masa remaja, seluruh organ seksual remaja akan mencapai kematangan. Pemahaman remaja tentang peran sosialnya serta kemampuan menjalankan peran sosial merupakan hal yang penting dipenuhi oleh remaja. Kemampuan siswa yang berasal dari sekolah homogen dalam menjalankan peran sosialnya berada pada kategori tinggi dengan ratarata skor adalah 53,12. Hal ini menunjukkan bahwa siswa tidak kesulitan dalam memahami dan menjalankan peran sosialnya sebagai laki-laki atau perempuan. Hal ini belum bisa dikatakan tidak mengalami masalah. Jika dibandingkan dengan siswa yang berasal dari sekolah heterogen skor tersebut masih lebih rendah.

Kemampuan remaja dalam menjalankan peran sosialnya sebagai laki-laki atau perempuan sangat diperlukan dalam kehidupan remaja. Salah satu alasan yang kuat dalam menggabungkan antara siswa laki-laki dan perempuan dalam satu kelas adalah agar mereka mampu memahami peran sosial mereka dan tidak berdampak buruk dalam hubungan sosial mereka selanjutnya. Sekolah homogen kurang dalam mempersiapkan siswanya untuk berinteraksi dengan teman lawan jenis sehingga hal ini akan menghambat peran siswa di masyarakat (Dale dalam Mael, 1998).

\section{Mencapai Perilaku Sosial yang Bertanggung Jawab}

Kemampuan remaja dalam mencapai perilaku sosial yang bertanggung jawab merupakan salah satu aspek kematangan sosial. Siswa yang berasal dari sekolah homogen memiliki skor rata-rata 67,57 sehingga bisa dikategorikan tinggi. Hal ini menunjukkan bahwa siswa yang berasal dari sekolah heterogen mampu mencapai perilaku sosial yang bertanggung jawab yang lebih tinggi dibandingkan dengan siswa yang berasal dari sekolah heterogen.

Berdasarkan fakta tersebut, terlihat bahwa siswa yang berasal dari sekolah homogen memiliki kemampuan mencapai perilaku sosial yang bertanggung jawab lebih tinggi dibandingkan dengan siswa yang berasal dari sekolah heterogen dikarenakan mereka berada di lingkungan yang menuntut untuk lebih bertanggung jawab. Ketika siswa dipisahkan secara jenis kelamin hal ini membuat mereka lebih mandiri dan bertanggung jawab. Pengelompokan siswa berdasarkan jenis kelamin akan membuat siswa lebih berpartisipasi aktif di kelas dan mampu melakukan tanggung jawab sosial (Ormrod, 2016).

Pengelompokan siswa berdasarkan jenis kelamin berdampak pada tanggung jawab sosial siswanya. Kemampuan remaja mencapai perilaku sosial yang bertanggung jawab tidak terlepas dari interaksi sosial yang dilakukan remaja dengan temannya. Teman-teman dan kelompok memberikan dorongan bagi remaja untuk mengambil peran dan tanggung jawab mereka (Desmita, 2011). Pengelompokan siswa berdasarkan jenis kelamin akan meminimalkan sikap agresi dari siswa lakilaki dan memaksimalkan sikap siswa perempuan yang dinilai cenderung pendiam.

\section{Kematangan Sosial Siswa Sekolah Heterogen}

Berdasarkan data pada Tabel 1, diketahui bahwa kematangan sosial siswa yang berasal dari sekolah heterogen berada pada kategori tinggi dengan rata-rata skor 164,95. Kategori kematangan sosial siswa yang berasal dari sekolah heterogen untuk aspek pertama yakni membina hubungan 
sosial dengan teman sejenis maupun lawan jenis adalah tinggi dengan rata-rata skor 44,20. Sedangkan rata-rata skor kematangan sosial siswa yang berasal dari sekolah heterogen untuk aspek kedua yaitu menjalankan peran sosial sesuai dengan jenis kelamin adalah 54,33 sehingga berada pada kategori tinggi. Sedangkan untuk aspek ketiga kematangan sosial siswa yang berasal dari sekolah heterogen berada pada kategori tinggi dengan rata-rata skor 66,42 .

Hasil analisis deskriptif menunjukkan bahwa rata-rata kematangan sosial siswa yang berasal dari sekolah heterogen berada pada kategori tinggi dengan skor 164,95. Hal tersebut menunjukkan bahwa kematangan sosial siswa yang tidak dipisahkan berdasar jenis kelamin lebih tinggi dibandingkan dengan siswa yang dipisah berdasar jenis kelamin.

Meskipun pemisahan siswa berdasarkan jenis kelamin tidak berpengaruh bagi siswa yang berasal dari sekolah homogen, yang dibuktikan dengan tingkat kematangan sosialnya yang tinggi, namun tingkat kematangan sosial siswa sekolah heterogen berada pada tingkat yang lebih tinggi. Hal ini menunjukkan bahwa kematangan sosial akan lebih tinggi jika siswa tidak dipisahkan berdasar jenis kelaminnya. Sekolah merupakan salah satu tempat bagi remaja untuk belajar berhubungan sosial dan tentunya akan dibawa oleh individu tersebut ketika berinteraksi nanti di masyarakat (Ormrod, 2016).

\section{Membina Hubungan Sosial dengan Teman Sejenis dan Lawan Jenis}

Berdasarkan hasil analisis data, rata-rata kemampuan siswa membina hubungan sosial dengan teman sejenis maupun lawan jenis berada pada kategori tinggi dengan skor 44,20. Kategori ini lebih tinggi dibandingkan dengan kemampuan siswa yang berasal dari sekolah homogen dalam membina hubungan sosial dengan sejenis maupun lawan jenis. Hal ini menunjukkan bahwa siswa yang tidak dipisahkan berdasar jenis kelamin memiliki kemampuan yang lebih tinggi dalam membina hubungan sosial dengan sejenis maupun lawan jenis dibandingkan dengan siswa yang dipisah berdasarkan jenis kelamin.

Berbeda dengan siswa yang berasal dari sekolah homogen, siswa yang berasal dari sekolah heterogen tidak dibatasai interaksi sosialnya dengan teman lawan jenis sehingga dapat meningkatkan kemampuan berhubungan sosialnya. Menurut Sullivan (dalam Santrock, 2003), siswa di sekolah heterogen tidak memiliki batasan untuk berinteraksi sosial antara siswa laki-laki dan perempuan sehingga mereka lebih cenderung mudah dalam mengembangkan persahabatan termasuk persahabatan antar jenis kelamin (Santrock, 2003).

Penggabungan siswa laki-laki dan siswa perempuan dalam satu kelas, akan membuat siswa belajar berinteraksi, saling belajar untuk memahami dan menghargai perbedaan, serta siswa lakilaki dapat belajar berkomunikasi dengan siswa perempuan begitu juga siswa perempuan dapat mempelajari kemampuan pemecahan masalah matematis dari siswa laki-laki, sehingga siswa lakilaki dan perempuan dapat memperluas diri mereka sendiri secara akademis dan emosional dengan berbagi pengetahuan, keterampilan, dan kemampuan (Wahyuni et al., 2014).

Tingginya tingkat kematangan sosial siswa yang berasal dari sekolah heterogen dibandingkan dengan siswa yang berasal dari sekolah homogen disebabkan karena mereka memiliki sekolah sebagai wadah untuk berinteraksi sosial. Kematangan sosial akan didapat oleh individu dengan cara berinteraksi sosial dengan lingkungannya(Indriana \& Windarti, 2008).

\section{Menjalankan Peran Sosial Sesuai dengan Jenis Kelamin}

Berdasarkan hasil analisis penelitian, ditemukan bahwa kemampuan siswa yang berasal dari sekolah heterogen dalam menjalankan peran sosialnya berada pada kategori tinggi dengan rata-rata skor adalah 54,33. Hal ini menunjukkan bahwa siswa tidak mengalami kesulitan dalam memahami dan menjalankan peran sosialnya sebagai laki-laki dan perempuan. Bukti ini diperkuat dengan tidak adanya siswa yang berada pada kategori rendah atau sangat rendah. Rata-rata skor siswa yang berasal dari sekolah heterogen lebih tinggi dibandingkan dengan rata-rata skor siswa yang berasal dari sekolah homogen, meskipun sama-sama berada pada kategori tinggi. 
Pada usia remaja, individu dituntut memenuhi segala tugas perkembangan sosialnya sehingga diharapkan mampu mencapai kematangan sosial. Salah satu aspek kematangan sosial atau tugas perkembangan tersebut adalah mampu menjalankan peran sosial sebagai laki-laki atau perempuan. Keadaan yang terjadi di sekolah heterogen yang tidak memisahkan siswa berdasarkan jenis kelamin merupakan salah satu upaya untuk memudahkan interaksi antara siswa yang berbeda jenis kelamin. Lebih lanjut, keadaan tersebut membuat siswa lebih mudah memahami peran sosialnya di lingkungan. Salah satu dari sikap positif bergaul dengan teman sebaya bagi remaja adalah mengembangkan sikap terhadap seksualitas dan tingkah laku peran jenis kelamin (Desmita, 2011).

Beraktivitas sesuai dengan jenis kelamin merupakan hal yang penting dilakukan oleh seorang individu agar mereka mampu memahami peran sosial serta memahami aktivitas yang sesuai dengan peran sosial tersebut. Meskipun remaja telah memahami konsep tentang peran sosialnya sejak mereka kecil, namun peran dari lingkungan akan memengaruhi pembentukan tersebut termasuk sekolah. Ketika remaja dihadapkan pada lingkungan sekolah yang membuat peran sosial mereka menjadi kabur, hal ini akan memberikan mereka kesulitan memahami peran sosial yang tepat bagi mereka. Meskipun tugas pembentukan identitas diri remaja sudah terbentuk sejak kecil namun perubahan lingkungan akan memengaruhi cara mereka memandang dirinya (Grotevant \& Cooper dalam Desmita, 2011).

\section{Mencapai Perilaku Sosial yang Bertanggung Jawab}

Kemampuan remaja dalam mencapai perilaku sosial yang bertanggung jawab merupakan salah satu aspek kematangan sosial. Siswa yang berasal dari sekolah heterogen memiliki skor rata-rata 66,42 sehingga masuk kategori tinggi. Skor tersebut masih rendah dari skor siswa yang berasal dari sekolah homogen. Berdasarkan hasil penelitian terlihat bahwa kemampuan siswa yang berasal dari sekolah heterogen dalam mencapai perilaku sosial yang bertanggung jawab lebih rendah dibandingkan dengan siswa yang berasal dari sekolah homogen. Perilaku sosial yang bertanggung jawab merupakan salah satu dampak dari hasil interaksi dengan individu dan kelompok lain. Temanteman dan kelompok memberikan dorongan bagi remaja untuk mengambil peran dan tanggung jawab mereka (Desmita, 2011).

Salah satu penyebab rendahnya kemampuan siswa yang berasal dari sekolah heterogen dalam mencapai perilaku sosial yang bertanggung jawab adalah lingkungan sekolah. Sekolah heterogen kurang memberikan pembelajaran dalam membentuk perilaku sosial yang bertanggung jawab. Pembelajaran remaja untuk mencapai perilaku sosial yang bertanggung jawab mestinya didapatkan oleh remaja di setiap lingkungannya. Remaja lebih mementingkan hubungan dengan teman sebaya dibandingkan dengan kegiatan belajarnya (Ormrod, 2016).

Di samping itu, salah satu penyebab rendahnya kemampuan siswa yang berasal dari sekolah heterogen dalam mencapai perilaku sosial yang bertanggung jawab adalah karena mereka berada di fase perkembangan remaja yang selalu ingin bebas. Pada saat memasuki fase remaja ini remaja berusaha dan bertindak layaknya seperti orang dewasa, mereka ingin lepas dari segala aturan yang telah ditetapkan oleh orang dewasa khususnya orangtua mereka (Desmita, 2011).

Rendahnya tingkah laku yang bertanggung jawab siswa sekolah heterogen dan tingginya tingkah laku yang bertanggung jawab siswa sekolah homogen disebabkan karena hampir semua aktivitas siswa sekolah homogen apalagi yang tinggal di pemondokan, dilakukan tanpa mengharapkan bantuan dari pihak lain termasuk siswa yang berbeda jenis kelamin dengannya (Aryani dalam Saraswati, 2013). Sedangkan siswa yang berasal dari sekolah heterogen cenderung bersikap kerjasama dengan memanfaatkan bantuan dari teman yang berbeda jenis kelaminnya.

\section{Perbedaan Kematangan Sosial Siswa yang Berasal dari Sekolah Homogen dan Heterogen}

Berdasarkan hasil analisis data yang dilakukan, terlihat ada perbedaan kematangan sosial siswa yang berasal dari sekolah homogen dan heterogen dengan $P$-value sebesar 0,31 . Hal ini menunjukkan bahwa ada perbedaan kematangan sosial yang signifikan antara siswa yang berasal dari sekolah 
homogen dan heterogen, dimana kematangan sosial siswa yang berasal dari sekolah heterogen lebih tinggi dibandingkan dengan siswa yang berasal dari sekolah homogen. Hal ini dibuktikan dengan lebih tingginya rata-rata skor kematangan sosial siswa yang berasal dari sekolah heterogen yakni 164,95 dibandingkan dengan rata-rata skor kematangan sosial siswa yang berasal dari sekolah homogen yaitu 160,1.

Siswa yang tidak dipisahkan berdasarkan jenis kelamin memiliki kematangan sosial yang lebih tinggi dibandingkan dengan siswa yang dipisah. Hal ini berlaku untuk semua aspek kematangan sosial kecuali untuk aspek mencapai perilaku sosial yang bertanggung jawab. Secara umum kematangan sosial siswa yang berasal dari sekolah heterogen lebih tinggi dibandingkan siswa yang berasal dari sekolah homogen.

Pada aspek kematangan sosial mampu membina hubungan sosial dengan sesama jenis maupun beda jenis kelamin, tingkat kematangan sosial siswa sekolah homogen lebih rendah dibandingkan siswa yang berasal dari sekolah heterogen. Kemampuan siswa sekolah homogen dalam membina hubungan sosial dengan teman sesama jenis dan lawan jenis berada pada ketegori sedang, sedangkan siswa yang berasal dari sekolah heterogen berada pada kategori tinggi. Kemampuan membina hubungan sosial yang dipengaruhi oleh dukungan sosial (Maslihah, 2011). Dukungan sosial berupa peraturan untuk tidak berinteraksi dengan lawan jenis membuat siswa sekolah homogen kesulitan dalam berhubungan sosial dengan lawan jenis.

Aspek kedua kematangan sosial yakni menjalankan peran sosial yang sesuai dengan jenis kelamin. Meskipun aspek menjalankan peran sosial siswa yang berasal dari sekolah homogen dan heterogen sama-sama berada pada kategori tinggi, secara rata-rata skor siswa yang berasal dari sekolah heterogen lebih tinggi dibandingkan dengan siswa yang berasal dari sekolah homogen. Faktor lingkungan sekolah juga berdampak pada kemampuan siswa dalam menjalankan peran sosialnya sebagai laki-laki dan perempuan. Pada aspek kedua ini kemampuan siswa dari sekolah homogen juga lebih rendah dibandingkan siswa dari sekolah heterogen. Salah satu penyebabnya adalah kurangnya interaksi sosial siswa yang berbeda jenis kelamin di sekolah homogen. Meskipun pemahaman siswa tentang siapa dirinya dan peran sosialnya sudah terbentuk dari kecil namun kurangnya interaksi sosial antar jenis kelamin juga berdampak pada pembentukan pamahamaan siswa tentang peran sosialnya (Maslihah, 2011) .

Aspek yang terakhir dari kematangan sosial adalah kemampuan mencapai perilaku sosial yang bertanggung jawab. Kemampuan siswa yang berasal dari sekolah homogen dalam mencapai perilaku sosial yang bertanggung jawab lebih tinggi dibandingkan dengan siswa yang berasal dari sekolah heterogen. Hal ini disebabkan karena siswa yang dipisahkan secara jenis kelamin lebih terbiasa mampu menjalankan semua aktivitas tanpa bergantung dengan siswa lain termasuk siswa yang berbeda jenis kelamin dengannya. Siswa yang dipisah berdasarkan jenis kelamin lebih sulit menjalin hubungan sosial yang lebih matang dengan teman sebaya dibandingkan dengan siswa yang tidak dipisah (Putra, 2017).

\section{SIMPULAN}

Secara rata-rata tingkat kematangan sosial siswa yang berasal dari sekolah homogen dan sekolah heterogen sama-sama berada pada kategori tinggi, namun kematangan sosial siswa yang berasal dari sekolah heterogen memiliki kematangan sosial yang lebih tinggi dibandingkan dengan kematangan sosial siswa yang berasal dari sekolah homogen. Saran ditujukan pada Guru BK atau Konselor Sekolah agar mampu memahami karakteristik siswa asuh, khususnya dalam hal kematangan sosial agar memudahkan ketika menentukan program yang tepat. Selanjutnya, perlu dilakukan penelitian lebih lanjut mengenai aspek-aspek yang memengaruhi kematangan sosial. Penelitian tersebut dapat menggunakan pendekatan kualitatif, sehingga lebih mendalam dan jelas. 


\section{DAFTAR RUJUKAN}

Ausubel, D. P. (2002). Theory and Problems of Adolescent Development. iUniverse.

Radjah, C. L. (2016). Keterampilan Konseling Berbasis Metakognisi. Jurnal Kajian Bimbingan dan Konseling, 1(3), 90-94. http://dx.doi.org/10.17977/um001v1i32016p090

Desmita, D. (2011). Psikologi Perkembangan Peserta Didik: Panduan bagi Orang Tua dan Guru dalam Memahami Psikologi Anak Usia SD, SMP, dan SMA. Bandung: Remaja Rosdakarya.

Hughes, T. A. (2006). The Advantages of Single-Sex Education. National Forum of Educational Administration And Supervision Journal, 23(2), 5-14.

Indriana, Y., \& Windarti, T. (2008). Mengembangkan Kematangan Sosial pada Anak Melalui Outbond. Sekolah Dasar: Kajian Teori dan Praktik Pendidikan, 17(2), 143-152.

Lestari, E. D., Hidayah, D., Suci, M. K., Riza, M., \& Martuti, S. (2005). 221 Factors Influencing Social Maturity among Obese Children at Elementary School in Surakarta. Pediatric Research, 58(2), 392. http://dx.doi.org/10.1203/00006450-200508000-00250

Mael, F. A. (1998). Single-sex and Coeducational Schooling: Relationships to Socioemotional and Academic Development. Review of Educational Research, 68(2), 101-129.

Maslihah, S. (2011). Studi tentang Hubungan Dukungan Sosial, Penyesuaian Sosial di Lingkungan Sekolah dan Prestasi Akademik Siswa SMPIT Assyfa Boarding School Subang Jawa Barat. Jurnal Psikologi, 10(2), 103-114. http://dx.doi.org/10.14710/JPU.10.2.103-114

Nicholls, A. R., Perry, J. L., Jones, L., Morley, D., \& Carson, F. (2013). Dispositional Coping, Coping Effectiveness, and Cognitive Social Maturity among Adolescent Athletes. Journal of Sport and Exercise Psychology, 35(3), 229-238. http://dx.doi.org/10.1123/jsep.35.3.229

Ormrod, J. E. (2016). Psikologi Pendidikan: Membantu Siswa Tumbuh dan Berkembang. Jakarta: Erlangga.

Putra, F. (2017). Ketercapaian Tugas-tugas Perkembangan Siswa Pondok Pesantren dan Implikasinya dalam Bimbingan dan Konseling. Jurnal Counseling Care, 1(1), 27-34.

Sadeghi, H. S., \& Niknam, M. (2015). The Relationship Between Coping Skills with Social Maturity and Adjustment of Female First Graders in High School: A Case Study in Iran. Asian Social Science, 11(25), 144-150. http://dx.doi.org/10.5539/ass.v11n25p144

Santrock, J. W. (2003). Adolescence: Perkembangan Remaja. Erlangga. Jakarta.

Saraswati, B. D. (2013). Sekolah Homogen... Ciptakan Kemandirian, namun Mampu Mengubah Orientasi Seksual | Joglosemar. Diambil 27 Desember 2017, dari http://edisicetak.joglosemar. co/berita/sekolah-homogen-ciptakan-kemandirian-namun-mampu-mengubah-orientasiseksual-111356.html

Singh, R., Pant, K., \& Valentina, L. (2013). Gender on Social and Emotional Maturity of Senior School Adolescents: A Case Study of Pantnagar. Stud Home Com Sci, 7(1), 1-6.

Wahyuni, W., Dewi, I., \& Hasratuddin, H. (2014). Perbedaan Peningkatan Kemampuan Pemecahan Masalah dan Komunikasi Matematis antara Siswa Kelas Heterogen Gender dengan Kelas Homogen Gender melalui Model Pembelajaran Berbasis Masalah di MTS Kota Langsa. Paradikma : Jurnal Pendidikan Matematika, 7(1). Diambil dari http://jurnal.unimed.ac.id/2012/ index.php/paradikma/article/view/1775 